\title{
KARAKTERISTIK MEDIASI PERBANKAN SEBAGAI ALTERNATIF PENYELESAIAN SENGKETA PERBANKAN INDONESIA (ANALISIS ASPEK KEADILAN, KEPASTIAN HUKUM, DAN KEMANFAATAN)
}

\author{
Oleh : \\ Nyoman Satyayudha Dananjaya, ${ }^{1}$ Kadek Agus Sudiarawan ${ }^{2}$
}

\begin{abstract}
There is difficulty in determining the position of mediation institutions as preferred of dispute resolution between the Bank and the Customers when viewed from the side of justice, legal certainty and the expediency that can be produced for the parties. On one side banking mediation has various advantages characteristic, but on the other side there are still many obstacles that must be overcome so that mediation can be applied effectively. Types of research used in this paper included the normative legal research which put the law as a norm building system. This research uses secondary data where all of these data are analyzed using the qualitative methods. The report of this study is presented in a descriptive analysis. From the aspect of justice, banking mediation conducted by Bank Indonesia need to have serious attention because it is not able to be objective that eventually will harm customers. Aspects of Legal Certainty, not maximal to set the authority for impose administrative sanctions to banks that do not comply with the contents of the mediation agreement and its become the main problem, and The Expediency Aspect: not yet known the extent of the banking institutions in community become barrier itself. So to address this dispute, independent mediation banking institutions should be formed by banking associations and Bank Indonesia needs to re-socialization the existence of banking mediation institutions to the public by displaying all of its advantages characteristic.
\end{abstract}

Keywords: Banking Mediation, Alternative Dispute Resolution, Aspect of Justice, Aspects of Legal Certainty, Aspects of Expediency

\footnotetext{
Abstrak

Terdapat kesulitan dalam menentukan kedudukan lembaga mediasi sebagai pilihan penyelesaian sengketa antara Bank dengan Nasabah jika ditinjau dari sisi keadilan, kepastian hukum dan kemanfaatan yang mampu dihasilkan bagi para pihak yang bersengketa. Disatu sisi mediasi perbankan memiliki berbagai keunggulan karakteristik, namun disisi lain masih banyak kendala yang harus dihadapi agar mediasi perbankan ini dapat terlaksana dengan efektif. Jenis penelitian yang digunakan dalam tulisan ini termasuk ke dalam penelitian hukum normatif yang meletakan hukum sebagai sebuah bangunan sistem norma. Data yang digunakan dalam penelitian ini adalah data sekunder data. Seluruh

Penulis pertama adalah Dosen Fakultas Hukum Universitas Udayana, Denpasar, Bali, alamat Jalan Pulau Bali No.1 Denpasar, email : satyayudhad@gmail.com

2 Penulis kedua adalah Dosen Fakultas Hukum Universitas Udayana, Denpasar, Bali, alamat Jalan Pulau Bali No.1 Denpasar, email: degust_ugm30@yahoo.co.id
} 
data yang terkumpul dianalisis dengan menggunakan metode kualitatif. Hasil penelitian disajikan dalam suatu laporan yang bersifat deskriptif analisis. Dari aspek keadilan mediasi perbankan yang dilaksanakan Bank Indonesia perlu mendapat perhatian serius karena dikhawatirkan tidak mampu bersikap obyektif yang akhirnya akan merugikan nasabah. Dari Aspek Kepastian Hukum : belum maksimalnya pengaturan mengenai kewenangan untuk menjatuhkan sanksi administratif kepada bank yang tidak mematuhi isi kesepakatan mediasi menjadi permasalahan utama, dan dari Aspek Kemanfaatan : belum dikenal luasnya lembaga mediasi perbankan di kalangan masyarakat menjadi faktor penghambat tersendiri. Sehingga untuk mengatasi permasalah ini lembaga mediasi perbankan independen oleh asosiasi perbankan harus segera dibentuk dan Bank Indonesia perlu mensosialisaikan kembali keberadaan lembaga mediasi perbankan kepada masyarakat luas dengan menampilkan segenap keunggulan karakteristik yang dimilikinya.

Kata Kunci : Mediasi Perbankan, Altenatif Penyelesaian Sengketa, Aspek Keadilan, Aspek Kepastian Hukum, Aspek Kemanfaatan

\section{PENDAHULUAN}

\subsection{Latar Belakang}

Lembaga Perbankan merupakan pokoksistemkeuanganyangmemegang peranan penting dalam sistem perekonomian dan menggerakkan pembangunan Indonesia. Dalam perkembangan kehidupan masyarakat modern seperti sekarang ini, tidak dapat dipungkiri bahwa dunia perbankan saat ini memiliki peranan penting dalam kehidupan manusia dan memegang posisi yang dominan, sebab bank merupakan penyedia dana bagi para pelaku usaha, sehingga pelaku usaha dapat menjalankan aktifitasnya, salah satunya adalah dalam bentuk pinjaman.

\begin{tabular}{lrr}
\multicolumn{1}{c}{ Bank } & sebagai financial \\
intermediary institution & selain \\
bertugas untuk & menghimpun dana \\
dan menjalankan usahanya terutama \\
dari dana masyarakat yang kemudian \\
menyalurkan kembali kepada
\end{tabular}

masyarakat, bank juga memberikan jasa-jasa keuangan dan pembayaran lainnya yang memudahkan masyarakat dalam kehidupan perekonomian dikesehariannya. ${ }^{3}$

Pengaturan mengenai perbankan di Indonesia dimulai sejak dilahirkannya UU No.14 Tahun 1967 tentang Pokok-Pokok Perbankan yang kemudian diganti dengan UU No.7 tahun 1992 Tentang Perbankan dan selanjutnya dengan Undang-Undang No.10 Tahun 1998 tentang Perubahan Atas UU No.7 Tahun 1992 Tentang Perbankan.

Dalam hal hubungan hukum yang terjadi antara bank dan nasabah, tidak dapat dipungkiri bahwa hubungan ini potensial akan menimbulkan sengketa antar pihak terkait. Adapun masalah dan sengketa antara nasabah dan

\footnotetext{
Burhanuddin Abdullah, 2006, Jalan Menuju Stabilitas Mencapai Pembangunan Ekonomi Berkelanjutan, Pustaka LP3ES Indonesia, Jakarta, hlm.203
} 
perbankan disebabkan oleh 4 (empat) hal utama yang meliputi :

1. Informasi yang kurang memadai mengenai karakteristik produk atau jasa yang ditawarkan bank.

2. Pemahaman nasabah terhadap aktivitas dan produk serta jasa perbankan yang masih kurang.

3. Ketimpangan hubungan antara nasabah dengan bank, khususnya bagi nasabah peminjam dana.

4. Tidak adanya saluran memadai untukmemfasilitasi penyelesaian friksi atau permasalahan yang terjadi antara nasabah dengan bank. $^{4}$

Bank Indonesia sebagai otoritas pengawas industri perbankan memiliki kepentingan dalam meningkatkan perlindungan hukum terhadap nasabah perbankan Indonesia. Adapun berbagai regulasi kemudian diterbitkan guna menguatkan perlindungan hukum terhadap nasabah diantaranya meliputi: Penerbitan regulasi dalam bidang perbankan mengenai perlindungan nasabah bank diantaranya adalah Penerbitan Peraturan Bank Indonesia (PBI) No. 7/6/PBI/2005 tentang Transparansi Informasi Produk Bank dan Penggunaan Data Pribadi Nasabah dan PBI No. 7/7/PBI/2005 tentang Penyelesaian Pengaduan Nasabah dan PBI No.8/5/PBI/2006 tentang Mediasi Perbankan.

4 Muliaman D. Hadad, Perlindungan dan Pemberdayaan Nasabah Bank Dalam Arsitektur Perbankan Indonesia, tercantum dalam URL : http://www.bi.go. iddiakses tgl 1 Maret 2016
Selama ini praktek perbankan Indonesia belum banyak menggunakan prosesnonlitigasidalammenyelesaikan sengketa. Hal ini dapat terlihat dari perjanjian-perjanjian oleh pihak bank dan masalah yang tidak mencantumkan klausula seperti arbitrase, mediasi, dan sebagainya seperti yang dikemukakan dalam Undang-Undang Nomor 30 Tahun 1999 Tentang Arbitrase dan Alternatif Penyelesaian Sengketa. Sejatinya ketidakpuasanketidakpuasan dalam penyelesaian sengketa di bidang perbankan sesungguhnya sangat terfokus pada keinginan untuk dapat menyelesaikan sengketa dengan cepat, tepat dan efektif. Penyelesaian sengketa melalui alternatif penyelesaian sengketa kemudian menjadi menarik untuk dianalisis dan dikembangkan lebih lanjut sebagai solusi penyelesaian sengketa perbankkan Indonesia.

Bank Indonesia kemudian mengeluarkan Peraturan Bank Indonesia Nomor 7/7/PBI/2005 tentang Penyelesaian Pengaduan Nasabah. Oleh karena dirasa kurang dapat memuaskan nasabah, Bank Indonesia sebagai pemegang otoritas tertinggi kemudian mengambil inisiatif untuk mengeluarkan Peraturan Bank Indonesia Nomor 8/5/PBI/2006 Jo Peraturan Bank Indonesia Nomor 10/1/ PBI/2008 Tentang Perubahan Atas Peraturan Bank Indonesia Nomor 8/5/ PBI/2006 tentang Mediasi Perbankan (PBI Mediasi Perbankan) yang mengatur secara lebih dalam dan rinci 
mengenai mediasi perbankan sebagai salah satu bentuk alternatif dispute resolution dalam menyelesaikan sengketa-sengketa perbankan di Indonesia.

Ketentuan-ketentuan hukum pada masa kolonial Belanda dan hingga masa-masa awal setelah kemerdekaan secara khusus memang tidak menegaskan secara kongkret mediasi sebagai salah satu bentuk penyelesaian sengketa, baik dipengadilan maupun diluar pengadilan. Ketentuan mengenai mediasi baru ditemukan dalam UU No.30 Tahun 1999 tentang Arbitrase dan Alternatif Penyelesaian Sengketa, Peraturan Pemerintah (PP) No.54 Tahun 2000 tentang Lembaga Penyedia Jasa Pelayanan Penyelesaian Sengketa Lingkungan Hidup di Luar Pengadilan dan PERMA No. 2 tahun 2003 tentang prosedur Mediasi di Pengadilan yang kemudian digantikan oleh PERMA No. 1 tahun 2008 dan dirubah dengan PERMA No.1 Tahun 2016.

Diterbitkannya UU No.30 Tahun 1999 membawa perubahan penting bagi pola penyelesaian sengketa dalam kehidupan masyarakat Indonesia. Keluarnya peraturan perundang-undangan ini membawa angin baru bagi para pihak yang ingin menyelesaikan sengketa diluar pengadilian. Undang-undang No.30 Tahun 1999 memberikan dorongan kepada para pihak bersengketa agar menunjukkan iktikad baik karena tanpa iktikad baik apapun yang diputuskan diluar pengadilan tidak akan dapat dilaksanakan. ${ }^{5}$ Prinsip win-win solution dan penyelesaian sengketa secara cepat telah menjadi pilihan dalam dunia bisnis akhir-akhir ini, sehingga keberadaan UU No.30 Tahun 1999 benar-benar memenuhi kebutuhan hukum masyarakat yang semakin berkembang.

Dalam konteks penyelesaian suatu sengketa perbankan, peranan lembaga mediasi sangatlah penting dalam upaya mencapai kesetaraan antara para pihak yang berada dalam konflik sehingga dapat menyelesaikan secara internal. Dimana salah satu upaya melalui mekanisme mediasi. ${ }^{6}$ Dewasa ini hampir semua negara mengembangkan berbagai jalan terobosan alternatif, karena kelemahan penyelesaiansengketamelaluiajudikasi yang mengakibatkan terkurasnya sumber daya, dana, waktu, pikiran dan tenaga, dan mulai mengedepankan pola-pola penyelesaian sengketa di luar pengadilan. ${ }^{7}$

Terkhusus dalam dunia perbankan Indonesia, proses mediasi sebagai salah satu bentuk penyelesaian sengketa alternatif merupakan kelanjutan dari pengaduan nasabah

Syahrizal Abbas, 2011, Mediasi Dalam Hukum Syariah,Hukum Adat dan Hukum Nasional, Kencana, Jakarta, hlm.139

Inosentius Samsul, 2009, Pengembangan Model Penyelesaian Sengketa Perbankan dalam Perpekstif Perlindungan Konsumen, dikutip dari Artikel dalam Buletin Hukum Perbankan dan_Kebanksentralan, Direktur Hukum Bank Indonesia, Jakarta, hlm.27-28.

Susanti Adi Nugroho, 2008, Proses Penyelesaian Sengketa Konsumen Ditinjau dari Hukum Acara serta Kendala Implementasinya, Kencana, Jakarta, hlm.13. 
apabila nasabah merasa tidak puas atas penanganan dan penyelesaian yang diberikan bank. Kehadiran mediasi perbankan dinilai sangat penting, dikarenakan selain penyelesaian melalui jalur ini dirasa lebih efektif dan lebih efisien bagi para pihak yang bersengketa.

\subsection{Perumusan Masalah}

Berdasarkan latar belakang diatas penulis kemudian tertarik untuk melakukan penelitian hukum dalam lingkup Hukum Perbankan Indonesia untuk berusaha menganalisis : Bagaimanakah karakteristik mediasi perbankan sebagai alternatif penyelesaian sengketa perbankan indonesia ditinjau dari sisi keadilan, kepastian hukum dan kemanfaatan yang mampu dihasilkan bagi para pihak yang bersengketa?

\subsection{Tujuan Penulisan}

Adapun tujuan dari penulisan ini ialah meliputi :

a. Untuk mengkaji dan mengetahui karakteristik mediasi perbankan sebagai alternatif penyelesaian sengketa perbankan indonesia ditinjau dari sisi keadilan, kepastian hukum dan kemanfaatan yang mampu dihasilkan bagi para pihak yang bersengketa

b. Untuk menambah wawasan dan pengetahuan bagi penulis di bidang ilmu hukum baik teori maupun praktek dalam hal ini lingkup Hukum Perbankan khususnya dibidang alternatif penyelesaian sengketa perbankan

c. Untuk menerapkan ilmu dan teori-teori hukum yang telah penulis peroleh agar dapat memberi manfaat bagi penulis sendiri secara khusus, institusi dan masyarakat pada umumnya.

\section{METODE PENELITIAN}

Penelitian hukum merupakan suatu kegiatan ilmiah, yang didasarkan pada metode, sistematika dan pemikiran tertentu yang bertujuan untuk mempelajari satu atau beberapa gejala hukum tertentu dengan jalan menganalisisnya secara lebih dalam. ${ }^{8}$

Jenis Penelitian yang digunakan dalam tulisan ini termasuk ke dalam penelitian hukum normatif yang meletakan hukum sebagai sebuah bangunan sistem norma. Data yang digunakan dalam penelitian ini adalah data sekunder. Seluruh data yang terkumpul dianalisis dengan menggunakan metode kualitatif. Hasil penelitian ini disajikan dalam suatu laporan yang bersifat diskriptif analisis. Bersifatdeskriptifkarenadaripenelitian ini diharapkan dapat memberikan gambaran secara menyeluruh dan sistematis mengenai asas-asas hukum, kaidah-kaidah hukum, doktrin dan peraturan perundang-undangan yang berkaitan dengan penelitian ini.

Soerjono Soekanto, 1986, Pengantar Penelitian Hukum, UI Press, Jakarta, hlm.43 
III. HASIL DAN PEMBAHASAN

\subsection{Analisis Aspek Keadilan}

Bank merupakan lembaga keuangan yang sangat dibutuhkan oleh masyarakat dalam melakukan transaksi keuangan, maupun transaksi lainnya. ${ }^{9}$ Dalam dinamika perjalanan suatu kegiatan perbankan, tidak bisa dipungkiri nasabah merupakan konsumen dari pelayanan jasa perbankan. Kedudukan nasabah dalam hubungannya dengan pelayanan jasa perbankan, berada pada dua posisi yang bergantian sesuai dengan sisi mana mereka berada. Pada dasarnya nasabah merupakan konsumen dari pelaku usaha yang menyediakan jasa di sektor usaha perbankan. ${ }^{10}$

Secara khusus saat kita berbicara mengenai aspek keadilan dari pengaturan mediasi perbankan. Analisis dapat dilakukan dengan membedah ketentuan-ketentuan dalam PBI Mediasi Perbankan dan menganalisis point-point strategis yang masih lekat dengan aspek ketidakadilan dalam pengaplikasian ketentuan tersebut, tentunya pisau analisis yang digunakan tidak lain ialah konsep sistem hukum Lawrence M.Friedman yang meliputi substansi, struktur dan budaya hukum. Dimana substansi, struktur dan budaya hukum yang menyebabkan aspek keadilan ini redup harus segera diformulasikan

\footnotetext{
$9 \quad$ Adiwidjaja dan Rivai Wirasasmita, 2000, Analisis Kredit, Bandung, CV Pionir Jaya, hlm.11.

10 Muhamad Djumhana, 2003. Hukum Perbankan di Indonesia, PT Citra, Bandung, hlm.282
}

ulang untuk meningkatkan efektifitas dan memperkuat nilai keadilan bagi pihak-pihak yang memilih menyelesaikan sengketanya melalui jalan mediasi perbankan.

\section{Substansi}

Ketentuan Pasal 3 ayat 4 PBI Mediasi Perbankan mengatur bahwa : sepanjang lembaga mediasi independen sebagaimana dimaksud pada ayat (1) belum dibentuk, fungsi mediasi perbankan dilaksanakan oleh Bank Indonesia, perlu mendapat perhatian karena dikhawatirkan BI tidak mampu bersikap obyektif yang akhirnya akan merugikan nasabah. Hal ini menjadi titik tolak lemahnya posisi nasabah dalam pelaksanaan suatu penyelesaian sengketa melalui mediasi perbankan. Selain itu ditegaskan pula oleh Mantan Direktur Investigasi dan Mediasi Perbankan Bank Indonesia Ahmad Fuad mengatakan bahwa, hal yang paling mendasar yang menjadi alasan segera dibentuknya mediasi oleh asosiasi perbankan adalah karena mediasi bukanlah tugas dari Bank Indonesia. Tugas Bank Indonesia yang sesungguhnya adalah untuk menjaga stabilitas moneter. ${ }^{11}$

\section{Struktur}

Secara struktur penyelenggaraan mediasi perbankan sendiri, idealnya

11 Bank Indonesia, 2009, Bank Indonesia Desak Lembaga Perbankan Segera Bentuk Mediasi, dikutip dari: http://www. hukumonline.com diakses pada 8 Maret 2016 
dilaksanakan oleh lembaga independen. Dengan dilaksankannya fungsi mediasi perbankan oleh lembaga independen maka proses mediasi akan lebih obyektif karena mediator tidak mempunyai kepentingan dalam sengketa yang tengah terjadi. Bank Indonesia sesungguhnya bukanlah lembaga resolusi konflik tetapi melaksanakan fungsi itu. Sesuai dengan ketentuan dalam Pasal 3 ayat (1), ayat (2) dan ayat (3) PBI No.8/5/PBI/2006, mediasi di bidang perbankan dimaksud dilakukan oleh suatu lembaga mediasi perbankan independen yang dibentuk asosiasi perbankan. Pembentukan lembaga mediasi perbankan independen tersebut dalam PBI tersebut diberi tenggat waktu pelaksanaan paling lambat pada tanggal 31 Desember 2007 dan ditentukan pula dalam pelaksanaan mediasi perbankan independen tersebut harus senantiasa dikoordinasikan dengan Bank Indonesia. Adapun asosiasi perbankan yang membentuk lembaga mediasi perbankan independen dapat terdiri dari gabungan asosiasi perbankan untuk menjaga independensinya. ${ }^{12}$

Berdasar pada ketentuan dalam Pasal 3 ayat (4) PBI No.8/5/PBI/2006, mengingat akan pembentukan lembaga mediasi perbankan independen tersebut

12 Erna Priliasari, 2008, Mediasi Perbankan Sebagai Wujud Perlindungan Terhadap Nasabah Bank, Artikel dalam Jurnal Legislasi Indonesia Volume 5 Nomor 2, Direktorat Jendral Peraturan Perundang-undangan Departemen Hukum dan Hak Asasi Manusia, Jakarta, hlm.43 tidak dapat dilaksanakan dalam waktu singkat, sementara kebutuhan mediasi perbankan sudah mendesak, maka pada tahap ini fungsi mediasi perbankan yang seharusnya dilaksanakan Bank Indonesia sampai pada akhir tahun 2007, maka berdasarkan Peraturan Bank Indonesia Nomor 10/1/PBI/2008 yang merupakan peraturan perubahan terhadap peraturan Bank Indonesia sebelumnya, karena hingga akhir tahun 2007 lembaga mediasi perbankan independen belum dapat dibentuk, sehingga untuk sementara waktu Bank Indonesia tetap melaksanakan fungsi mediasi sampai dengan terbentuknya lembaga mediasi perbankan independen oleh asosiasi perbankan ini merupakan salah satu faktor mengapa dari sekian banyak sengketa yang masuk untuk diselesaikan melalui mediasi perbankan, masih sangat sedikit yang dapat diselesaikan dengan tuntas.

\section{Budaya Hukum}

Terkait dengan aspek budaya hukum, hambatan juga datang dari dalam operasional mediasi perbankan sendiri. Dengan institusi lembaga penyelesaian sengketa perbankan yang dilaksanakan oleh Bank Indonesia tersebut bisa mempengaruhi sikap dan perilaku Bank Indonesia lebih merasa sebagai hakim dalam penyelesaian sengketa nasabah dari pada sebagai mediator. Apabila mediator Bank Indonesia menggunakan pendekatan yang bersifat legal-positivistik, 
dimana pendekatan legal-positivistik seharusnya dihindarkan karena karakteristik sengketa nasabah bank seringkali bersifat khas dan komplek sehingga memerlukan cara penyelesaian yang komperhensif. Selain itu juga karena sengketa nasabah dengan bank mempunyai tingkat ketimbangan posisi tawar yang besar, dimana bank berada dalam posisi yang jauh lebih kuat dari nasabah.

Kekhawatiran mediasi akan menyelesaikan sengketa yang berpangkal pada pemahaman normatif sempit merupakan salah satu hal yang juga menjadi penyebab terhambatnya pelaksanaan penyelesaian sengketa melalui mediasi perbankan. Seringkali proses mediasi berujung pada hasil sepakat atau tidak sepakat" hanya karenaterlalukakuterhadapaturanbatas waktu penyelesaian sengketa. Contoh kegagalan lainnya misalnya pengaduan nasabah ditolak hanya karena terlalu sempit dalam menafsirkan pengertianpengertian tertentu sehingga akan sangat merugikan nasabah. ${ }^{13}$

Selain pandangan-pandangan diatas menurut data Bank Indonesia bahwa mediasi perbankan sendiri sebenarnya belum dikenal luas oleh nasabah. Masih banyak nasabah yang tidak mengetahui keberadaannya meskipun Bank Indonesia mewajibkan tiap bank memberikan informasi tentang hak-hak nasabah termasuk

13 Herliana, 2011, Peran Bank Indonesia dalam Mediasi Perbankan, tercantum dalam URL : http://www.hukumonline.com diakses tanggal 8 Maret 2016, hlm.153 mediasi. Minimnya informasi dari bank ini menyebabkan sebagian nasabah berhenti pada tahap pengaduan nasabah saja, tanpa melanjutkan proses ke mediasi meskipun mereka tidak puas dengan penyelesaian sengketa yang dimilikinya. Hal ini membuktikan bahwasanya apa yang diamanatkan dalam ketentuan Pasal 14 PBI Mediasi Perbankan dan Surat Edaran Bank Indonesia Nomor 8/14/DPNP yang menentukan kewajiban publikasi oleh bank terkait adanya sarana mediasi perbankan dan kewajiban publikasi melalui media-media publikasi sebagaimana ditentukan surat edaran tersebut belum dilaksanakan secara maksimal.

\subsection{Analisis Aspek Kepastian Hukum}

Dengan semakinberkembangnya dunia perbankan Indonesia yang kemudian diwarnai oleh berbagai sengketa-sengketa yang terjadi antara bank dan nasabah. Dalam konteks perlindungan terhadap nasabah ini, Yayasan Lembaga Konsumen Indonesia (YLKI) juga melihat bahwa nasabah seringkali mengalami kesulitan dalam mencari penyelesaian sengketa dengan bank. YLKI telah berperan dalam menyelesaikan sengketa perbankan antara nasabah dengan bank sebelum terbentuknya lembaga mediasi perbankan. Namun demikian, terdapat beberapa kelemahan yang membuat posisi YLKI cenderung tidak kuat, dimana 
seringkali beberapa dari bank yang terlibat tidak mengindahkan surat panggilan dari YLKI meskipun YLKI telah mendapat kepercayaan dari nasabahyangmenderitakerugian. Bank menyampaikan argumentasinya bahwa YLKI tidak memiliki kewenangan untukmemaksabankuntukmenanggapi atau datang memenuhi panggilan. Akibatnya, sengketa nasabah tidak dapat memperoleh penyelesaian secara tuntas dan berkeadilan. ${ }^{14}$

Padahal jika dianalisis lebih dalam, sesungguhnya YLKI memiliki mekanismeyangefektifuntukmemaksa bank mengindahkan panggilan YLKI untuk menyelesaikan sengketa dengan nasabah yaitu melalui media massa. Kredibilitas YLKI yang terpercaya di masyarakat dapat dijadikan senjata dengan memberitakan bank mana yang mempunyai track record bagus sehubungan dengan pelayanan konsumen dan mana yang tidak. Namun, hal ini tidak dilaksanakan karena akibatnya akan membahayakan kepercayaan masyarakat terhadap bank tertentu.

Kondisi sebagaimana dipaparkan diatas kemudian kembali terulang dan masih sering terjadi ketika Lembaga Mediasi Perbankan ini muncul dan diampu oleh Bank Indonesia sebelum terbentuknya asosiasi perbankan independen. Hal ini tak lain disebabkan oleh masih belum kuatnya ketentuan-ketentuan dalam PBI Mediasi perbankan mengatur

${ }_{14} \quad$ Herliana, op.cit, hlm.147 secara tegas atau memberi kepastian hukum terhadap pihak-pihak yang bersengketa terutama bagi pihak perbankan yang ada diposisi dominan, sehingga ketidakpastian hukum ini kemudian seringkali merugikan pihakpihak yang bersengketa.

\section{Substansi}

Dari sisi substansi ketentuanketentuan seperti: pada pengaturan pelaksanaan dan penuangan hasil kesepakatan perdamaian (kaitannya denganPasal13 PBIMediasiPerbankan tentang kewajiban Bank dalam pelaksanaan hasil kesepakatan dan penuangan dalam akta kesepakatan). Efektifitasnya sangat tergantung dari itikad baik para pihak menaati hasil kesepakatan tersebut. Apabila salah satu pihak tidak mau melaksanakan kesepakatan yang telah dicapai, tidak ada upaya hukum yang dapat dilakukan untuk memaksakannya dan tidak diatur pula tentang pendaftaran kesepakatan. Kelemahan ini telah diusahakan untuk diatasi oleh Peraturan Bank Indonesia tentang Mediasi Perbankan. Dimana, dalam hal ini Bank Indonesia diberikan pengaturan mengenai kewenangan untuk menjatuhkan sanksi administratif (Pasal 16 angka 1 PBI Mediasi Perbankan) kepada bank yang tidak mematuhi isi kesepakatan mediasi. Bentuk sanksi tersebut berupa teguran tertulis serta diperhitungkannya ketidakpatuhan itu dalam komponen penilaian tingkat kesehatan bank (Pasal 16 angka 2 
PBI tentang Mediasi Perbankan). Pemberian sanksi oleh Bank Indonesia sebagai lembaga ekternal (ekternal authority) dapat dibenarkan demi efektifitasnya mediasi. Namun demikian, sanksi dari Bank Indonesia tersebut belum cukup maksimal untuk memberi perlindungan kepada nasabah. Sanksi dari Bank Indonesia tidak bersifat tegas dan memaksa agar bank melaksanakan kewajibannya, tetapi lebih kepada sanksi administratif dan sanksi sosial saja. Nasabah yang dirugikan tidak dapat menggunakan upaya hukum untuk mendapatkan ganti kerugian yang menjadi haknya.

Disamping itu PBI tentang Mediasi Perbankan tidak mengatur mengenai sanksi apabila nasabah tidak mau melaksanakan kesepakatan. Penentuan bahwa yuridiksi mediasi adalahsengketaantaranasabahdanbank yang disebabkan tidak dipenuhinya tuntutan finansial nasabah oleh bank, tidak menghilangkan kemungkinan bahwa dalam hasil kesepakatan mediasi juga terdapat kewajiban atau prestasi yang dibebankan kepada nasabah.

\section{Struktur}

Dari sisi struktur dapat dianalisis bahwa lembaga pelaksana mediasi perbankan yaitu Bank Indonesia sendiri mengalami kesulitan untuk menghubungi pejabat di bank yang berkompeten untuk dipanggil dan menjalani proses mediasi. Seringkali, utusan yang dikirim oleh bank tidak memiliki kewenangan memutus. Hal ini disebabkan belum terdapat suatu pengaturan khusus yang mampu mengikat dan memberi kepastian hukum terkait kewajiban bank secara mendetail terkait pelaksanaan mediasi perbankan beserta sanksi-sanksi yang tegas bagi pihak-pihak yang tidak patuh kepadanya. Hal ini berakibat proses mediasi tidak dapat berjalan sebagaimana mestinya sebab staff tidak dapat menawarkan opsi-opsi atau memberikan alternatif penyelesaian masalah. Sehingga proses mediasi tidak berjalan efektif dan membutuhkan waktu lama.

\section{Budaya Hukum}

Kemudian dari sisi budaya hukum kaitannya dengan Kepastian Hukum dapat dilihat dari Fakta dilapangan yang menunjukkan bahwa masih banyak pejabat bank yang belum mengetahui ketentuan mediasi perbankan. Salah seorang narasumber yang merupakan staff salah satu Bank yang memiliki kantor cabang diberbagai daerah pun mengatakan bahwa ia dan beberapa rekannya tidak memahami mediasi perbankan. Menurutnya, apabila terjadi konflik dengan nasabah dengan salah satu kantor cabang, maka akan diselesaikan di kantor cabang tersebut oleh staf bank yang bersangkutan. Apabila nasabah tidak puas maka sengketa diteruskan kepada kantor wilayah yang membawahi cabang tersebut. Apabila masih terdapat ketidakpuasan maka akan diteruskan dikantor pusat 
di Jakarta.

Narasumber tersebut menyatakan belum pernah mendapati sengketa melibatkan bank tersebut dengan nasabahnya diselesaikan dengan mediasi perbankan di Bank Indonesia. Lebih lanjut ia menyatakan bahwa beresiko bagi bank yang menjadi tempatnya bekerja untuk menyelesaikan sengketa ke Bank Indonesia karena akan berpengaruh terhadap reputasi bank sendiri. Dengan alasan tersebut, maka kantor pusat kemudian akan berusaha semaksimal mungkin menyelesaikan sengketa dengan nasabahnya. Jadi dalam hukum terdapat bentrokan yang tak dapat dihindarkan, pertikaian yang selalu berulang antara tuntutan-tuntutan keadilan dan tuntutan-tuntutan kepastian hukum. Makin banyak hukum memenuhi syarat, peraturan tetap, yang sebanyak mungkin meniadakan ketidakpastian, jadi makin tepat dan tajam peraturan hukum itu, makin terdesaklah keadilan.

\subsection{Analisis Aspek Kemanfaatan}

Sesuai dengan data statistik Bank Indonesia terkait sengketa-sengketa yang diajukan penyelesaiannya melalui mediasi perbankan, didapat bahwasanya sejak dibuka pada Januari 2006 mediasi perbankan disambut dengan positif oleh nasabah perbankan Indonesia. Hal ini terbukti dari antusiasme nasabah dalam mengadukan sengketa mereka ke mediasi perbankan. Data statistik tentang jumlah sengketa menunjukkan pada sejak bulan Januari 2006 hingga Desember 2006 jumlah pengaduan dan permohonan penyelesaian sengketa melalui mediasi Bank Indonesia tercatat sebanyak 151 sengketa. ${ }^{15}$

Kemudian pada tahun 2007 berdasarkan data Bank Indonesia, sepanjang 2007 Bank Indonesia telah menerima sebanyak 64.288 pengaduan. Dari jumlah itu, 97,8 persen pengaduan adalah pengaduan nasabah di bidang sistem pembayaran. Sisanya, pengaduan di bidang penghimpunan dana, penyaluran dana, produk kerja sama dan produk lainnya. Dari seluruh pengaduan itu, permintaan penyelesaian dengan cara mediasi sebanyak 200 sengketa. Sampai akhir 2007, Bank Indonesia telah menyelesaikan 90 persen sengketa dan sisanya sedang dalam proses penyelesaian. ${ }^{16}$

Dalam perkembangan kemudian, penyelesaian sengketa melalui mediasi perbankan pada tahun 2008 hingga 2012 dari segi kuantitas pengajuan sengketa nasabah dengan bank telah mengalami peningkatan pesat. Data statistik Bank Indonesia menyebutkan, penanganan sengketa mediasi perbankan sejak Januari hingga Juni 2008 adalah 158 kasus. Dari jumlah tersebut sebanyak 89 kasus selesai tanpa mediasi, 60 kasus sedang

\footnotetext{
15 Bank Indonesia, 2012, Data Penyelesaian Bank Indonesia, hal.155, dikutip dari http://www.bi.go.id/web/id, diakses pada 13 Maret 2016.

$16 \quad$ Ibid, hlm.156
} 
diproses, 6 kasus diselesaikan oleh bank dan 3 kasus diselesaikan dengan mediasi perbankan. Dan hingga untuk triwulan tahun 2012 ini sudah terdapat 148 kasus perbankan, dan yang bisa dimediasi hanya 25 kasus, dan jika dihitung hingga Desember 2011 lalu terdapat 510 kasus perbankan yang terjadi di dunia perbankan Indonesia. Kondisi demikian kemudian terus terjadi hingga tahun 2015 dimana sangat sedikit sengketa yang dapat diselesaikan melalui mediasi perbankan. Hal ini menunjukkan masih lemahnya tingkat penyelesaian kasus atau sengketa perbankan melalui Alternatif Penyelesaian Sengketa di Indonesia di tengah maraknya kasus atau sengketa yang terjadi di dunia perbankan Indonesia. ${ }^{17}$

Berdasarkan uraian data statistik diatas, dapat dianalisis bahwa terdapat beberapa faktor yang menjadi penyebab dan mempengaruhi masih lemahnya tingkat penyelesaian sengketa melalui mediasi perbankan di Indonesia yang antara lain meliputi beberapa hal utama seperti adanya beberapa ketentuan dalam Peraturan Bank Indonesia mengenai Mediasi Perbankan yang memiliki beberapa kelemahan.

\section{Substansi}

Analisis dari sisi Substansi yang kemudian sangat berkorelasi dengan aspek kemanfaatan dari berlakunya PBI Mediasi Perbankan ini dapat dicermati dalam beberapa ketentuan pasal-pasal dalam PBI ini yang mereduksi aspek kemanfaatan itu sendiri dengan ketentuan-ketentuan yang menyulitkan pihak-pihak yang bersengketa, yang diantaranya meliputi : ketentuan yang menyatakan bahwa semua permohonan mediasi harus ditujukan kepada Direktorat Investigasi dan Mediasi Perbankan di Kantor Pusat Bank Indonesia di Jakarta (Pasal 15 PBI Mediasi Perbankan), dipercaya sebagai faktor penghambat penyelesaian sengketa yang efektif.

Disamping alasan kepraktisan, terutama bagi nasabah yang berdomisili di luar Jawa, juga masalah efisiensi waktu. Akan dibutuhkan waktu yang relatif lama untuk Direktorat Investigasi dan Mediasi dapat menangani semua kasus yang terjadi di seluruh Indonesia. Dari segi kepraktisan dan biaya pelaksanan mediasi perbankan. Meskipun proses mediasi dapat dilakukan di kantor Bank Indonesia yang paling dekat dengan domisili nasabah atau bank, mediator tetaplah dari kantor Bank Indonesia Jakarta. Hal ini berimbas pada besarnya biaya yang harus dikeluarkan Bank Indonesia dalam menjalankan fungsi mediasi. Akan lebih efisien bila Bank Indonesia didaerah diberi kewenangan untuk melaksanakan fungsi mediasi perbankan ini.

Selain itu secara substansi menurut data Bank Indonesia bahwa mediasi perbankan sendiri sebenarnya belum dikenal luas oleh nasabah. 
Masih banyak nasabah yang tidak mengetahui keberadaannya meskipun Bank Indonesia mewajibkan tiap bank memberikan informasi tentang hak-hak nasabah termasuk mediasi. Minimnya informasi dari bank ini menyebabkan sebagian nasabah berhenti pada tahap pengaduan nasabah saja, tanpa melanjutkan proses ke mediasi meskipun mereka tidak puas dengan penyelesaian sengketa yang dimilikinya. Hal ini membuktikan bahwasanya apa yang diamanatkan dalam ketentuan Pasal 14 PBI Mediasi Perbankan dan Surat Edaran Bank Indonesia Nomor 8/14/DPNP yang menentukan kewajiban publikasi oleh bank terkait adanya sarana mediasi perbankan dan kewajiban publikasi melalui media-media publikasi sebagaimana ditentukan surat edaran tersebut belum dilaksanakan secara maksimal.

\section{Struktur}

Terkait dengan struktur dalam pelaksanaan mediasi perbankan yang sangat berkorelasi dengan aspek kemanfaatan ialah mediator. Hal ini dapat kita temukan seperti pada ketentuan Pasal 5 ayat (1) PBI Nomor 8/5/PBI/2006 dan PBI No.10/1/PBI/2008 tentang Mediasi Perbankan yang menyatakan bahwa : Bank Indonesia menunjuk mediator, namun tidak menjelaskan (selama belum dibentuk Lembaga Mediasi Independen) apakah mediator berasal dari intern Bank Indonesia atau staff dari Bank Indonesia ataupun mediator professional. Ayat (2) menyebutkan tentang syarat mediator yaitu mempunyai pengetahuan perbankan, keuangan atau hukum, tidak mempunyai kepentingan dengan para pihak dan tidak mempunyai kepentingan dengan para pihak dan tidak mempunyai hubungan darah maupun semenda dengan para pihak.

Dari syarat-syarat tersebut, dapat diasumsikan bahwa mediator yang ditunjuk Bank Indonesia bisa berasal dari dalam Bank Indonesia atau internal Bank Indonesia ataupun dari luar Bank Indonesia, asalkan memenuhi syarat-syarat yang telah ditetapkan. Analisis terhadap ketentuan menurut pandangan penulis, selayaknya selain syarat yang telah dicantumkan tersebut hendaknya ditambahkan bahwa seorang mediator harus mempunyai sertifikat mediator.

Dalam praktek-praktek mediasi di pengadilan, ketidakberhasilan hakim berperan sebagai mediator banyak disebabkan oleh karena mereka tidak mendapatkan pelatihan mediator sehingga tidak menerapkan teknik dan strategi mediasi yang benar. Apabila Bank Indonesia tidak mensyaratkan adanya sertifikat mediator bagi para mediatornya, dari Aspek Kemanfaatan bukan tidak mungkin bahwa mediasi perbankan akan banyak mengalami kebuntuan, walaupun yang berperan sebagai mediator adalah ahli dalam bidang perbankan, hukum ataupun ekonomi. Pengetahuan substansi 
permasalahan yang disengketakan walaupun perlu untuk dimiliki oleh seorang mediator, namun tidak mutlak dibutuhkan. Hal ini disebabkan menurut praktek mediasi, mediator maupun para pihak diperkenankan untuk meminta bantuan ahli untuk dimintai pendapat atas sengketa yang sedang berlangsung. Adapun nilai terpenting yang harus dimiliki oleh seorang mediator adalah kemampuan menganalisisdankeahlianmenciptakan pendekatan pribadi. ${ }^{18}$

\section{Budaya Hukum}

Dari aspek budaya hukum penyelesaian sengketa dengan cara mediasi belum membudaya di kalangan masyarakat. Sehingga untuk kondisi demikian sangat diperlukan sosialisasi dan pubikasi maksimal terkait keberadaan lembaga mediasi perbankandankeunggulan-keunggulan penyelesaian sengketa melalui mediasi perbankan.

Permasalahan lain yang juga seringkali ditemukan ialah nasabah yang kurang memahami kasus posisi yang sebenarnya, nasabah juga tidak memberikan dokumen yang lengkap, serta tidak mencantumkan telepon yang bisa dihubungi untuk proses klarifikasi oleh Direktorat Investigasi dan Mediasi Perbankan Bank Indonesia. Hal-hal yang sifatnya teknis seringkali menjadi penghambat pelaksanaan mediasi perbankan dapat berlangsung secara lebih praktis dan efisien.

18 Suyud Margono, 2000, ADR dan Arbitrase Proses Pelembagaan dan Aspek Hukum, Ghalia Indonesia, Jakarta, hlm,47.
Kelemahan dan beberapa faktor penghambat inilah yang kemudian membuat pengaplikasian mediasi perbankan sebagai alternatif penyelesaian sengketa masih kurang maksimal. Diperlukan suatu metodemetode pendukung untuk memperkuat pelaksanaan mediasi sebagai pilihan yang tepat, yang apabila dibandingkan dengan bentuk penyelesaian lainnya, mediasi perbankan memiliki begitu banyak keunggulan karakteristik yang akan memberikan banyak keuntungan bagi nasabah dan bank.

\section{PENUTUP}

\subsection{Simpulan}

Berdasarkan

uraian permasalahan yang telah dibahas, maka dapat ditarik simpulan yakni sebagai berikut :

\section{- Analisis Aspek Keadilan :}

Mediasi Perbankan yang dilaksanakan Bank Indonesia sepanjang lembaga mediasi independen belum terbentuk perlu mendapat perhatian serius karena dikhawatirkan tidak mampu bersikap obyektif yang akhirnya akan merugikan nasabah. Idealnya mediasi perbankan dilaksanakan oleh lembaga independen. Selain itu Pendekatan legal-positivistik yang dilakukan oleh Bank Indonesia dalam proses mediasi perbankan seharusnya dihindarkan karena karakteristik sengketa nasabah bank seringkali bersifat khas dan kompleks sehingga memerlukan cafra penyelesaian yang kompregensif. 


\section{- Analisis Aspek Kepastian}

Hukum : pengaturan pelaksanaan dan penuangan hasil kesepakatan perdamaian efektifitasnya sangat tergantung dari itikad baik para pihak menaati hasil kesepakatan tersebut dan pengaturan mengenai kewenangan untuk menjatuhkan sanksi administratif kepada bank yang tidak mematuhi isi kesepakatan mediasi belum cukup maksimal untuk memberi perlindungan kepada nasabah. Sanksi dari Bank Indonesia tidak bersifat tegas dan memaksa agar bank melaksanakan kewajibannya.

Analisis

Aspek

Kemanfaatan:ketentuanbahwa semua permohonan mediasi harus ditujukan kepada Direktorat Investigasi Mediasi Perbankan di Kantor Pusat Bank Indonesia di Jakarta dan penyelesaian sengketa melalui mediasi yang belum membudaya dikalangan masyarakat merupakan salah satu faktor penghambat penyelesaian sengketa secara efektif

\subsection{Saran}

Berdasarkan data dan simpulan yang diperoleh, maka adapun saran yang dapat diberikan antara lain :

- Lembaga mediasi perbankan independen perlu segera dibentuk oleh asosisasi perbankan sebagai bentuk tanggung jawab dalam memberi perlindungankepada nasabah bank secara maksimal dan mengembalikan fungsi Bank Indonesia untuk menjaga stabilitas moneter.
Diperlukan suatu pengaturan sanksi yang tegas dan memaksa dari Bank Indonesia agar bank melaksanakan kewajibannya untuk bertanggung jawab dan memenuhi segala bentuk mekanisme penyelesaian sengketa melalui mediasi sehingga dapat meningkatkan efektifitas mediasi perbankan sebagai alternatif penyelesaian sengketa antara bank dan nasabah yang memiliki begitu banyak keunggulan karakteritik. Bank Indonesia perlu mensosialisaikan kembali keberadaan lembaga mediasi perbankan kepada masyarakat dengan menegaskan kewajiban setiap bank untuk menginformasikan pada nasabahnya akan ketersediaan mediasi perbankan dan berani memberikan sanksi yang tegas bagi bankbank yang bermain dan tidak melaksanakan kewajibannya secara maksimal.

\section{DAFTAR BACAAN}

\section{Buku}

Adiwidjaja dan Rivai Wirasasmita, 2000,Analisis Kredit, CV Pionir Jaya, Bandung.

Burhanuddin Abdullah, 2006. Jalan Menuju Stabilitas Mencapai Pembangunan Ekonomi Berkelanjutan, Pustaka LP3ES Indonesia, Jakarta. 
Erna Priliasari, 2008. Mediasi Perbankan Sebagai Wujud Perlindungan Terhadap Nasabah Bank, Direktorat Jendral Peraturan Perundang-undangan Departemen Hukum dan Hak Asasi Manusia, Jakarta.

Inosentius Samsul, 2009.

Pengembangan Model

Penyelesaian Sengketa

Perbankan dalam Perpekstif

Perlindungan Konsumen,

Direktur Hukum Bank Indonesia, Jakarta.

Muhamad Djumhana, 2003. Hukum

Perbankan di Indonesia, PT

Citra, Bandung.

Soerjono Soekanto, 1986, Pengantar

Penelitian Hukum, UI Press, Jakarta

Susanti Adi Nugroho, 2008. Proses

Penyelesaian

Sengketa

Konsumen Ditinjau dari

Hukum Acara serta Kendala Implementasinya, Kencana, Jakarta.

Suyud Margono, 2000. ADR dan Arbitrase Proses Pelembagaan dan Aspek Hukum, Ghalia Indonesia, Jakarta.

Syahrizal Abbas, 2011. Mediasi Dalam Hukum Syariah,Hukum Adat dan Hukum Nasional, Kencana, Jakarta.

\section{Artikel}

Muliaman D. Hadad, Perlindungan dan Pemberdayaan Nasabah Bank Dalam Arsitektur Perbankan
Indonesia, tercantum dalam URL: $\quad$ http://www.bi.go.id, diakses pada tanggal 1 Maret 2016.

Bank Indonesia, 2009, Bank Indonesia Desak Lembaga Perbankan Segera Bentuk Mediasi, dikutip dari http://www.hukumonline. com /diakses pada 8 Maret 2016.

Herliana, 2011, Peran Bank Indonesia dalam Mediasi Perbankan, tercantum dalam URL : http://www.hukumonline.com/, diakses tanggal 8 Maret 2016.

Bank Indonesia, Data Bank Indonesia terhadapKasus-KasusPerbankan melalui Mediasi, tercantum dalam URL : http://www.bi.go. $\mathrm{id} / \mathrm{web} / \mathrm{id} /$, diakses tanggal 13 Maret 2016.

3. Peraturan

PerundangUndangan

Undang-Undang Nomor 30 Tahun 1999 Tentang Arbitrase dan Alternatif Penyelesaian Sengketa, Lembaran Negara Republik Indonesia Tahun 1999 Nomor 138.

Undang-Undang Nomor 10 tahun 1998 Tentang Perubahan Atas Undang-Undang Nomor7 Tahun 1992 Tentang Perbankan, Lembaran Negara Republik Indonesia Tahun 1998 Nomor 182

Peraturan Bank Indonesia Nomor 7/7/ PBI/2005 Tentang Penyelesaian 
Pengaduan Nasabah, Lembaran

Negara Republik Indonesia

Tahun 2005 Nomor 17 DPNP/

$\mathrm{DPbs} / \mathrm{DPBPR}$

Peraturan Bank Indonesia Nomor

10/10/PBI/2008 Tentang

Perubahan Atas Peraturan Bank

Indonesia Nomor 7/7/PBI/2005

TentangPenyelesaianPengaduan

Nasabah, Lembaran Negara

Republik Indonesia Tahun 2008

Nomor 38 DPNP/UKMI/DPbs/

DKBU

Peraturan Bank Indonesia Nomor

8/5/PBI/2006 Tentang Mediasi

Perbankan, Lembaran Negara

Republik Indonesia Tahun 2006

Nomor DPNP/DPbS/DPBPR

Peraturan Bank Indonesiia Nomor

10/1/PBI/2008 Tentang

Perubahan Atas Peraturan Bank

Indonesia Nomor 8/5/PBI/2006

Tentang Mediasi Perbankan,

Lembaran Negara Republik

Indonesia Tahun 2008 Nomor

$10 \mathrm{DPN} / \mathrm{DPbs} / \mathrm{DPBR}$

Surat Edaran Mahkamah Agung

No.8/14/DPNP Perihal Mediasi

Perbankan. 